\title{
Physical aspects of the interaction of pyrimidine and purine bases with proteins
}

\author{
A. Sułkowska \\ Department of Physical Pharmacy, Medical University of Silesia, Jagiellońska 4, 41-200 Sosnowiec, \\ Poland \\ Tel.: +48 32 2925541, ext.383; Fax: +48 32 2667860; E-mail: annasulkowska@yahoo.com
}

\begin{abstract}
The study of complexation of purine and pyrimidine derivatives with two kind of serum albumin using ${ }^{1} \mathrm{H}$ NMR and spectrofluorescence technique are performed in order to obtain model interactions nucleic acid bases-protein.

The order of binding strength is as follows: $5 \mathrm{mC}>5 \mathrm{mU}(\mathrm{T})>3 \mathrm{mU}>\mathrm{U}$ for pyrimidines and N6mAde $>$ N6Ado $>1 \mathrm{mAde}$ $>$ ATP $>$ Ado $>$ Ade for adenine derivatives.

The effect of temperature on the hydrophobic interaction between the nitrogen bases and protein has been studied. The destabilization of protein structure causes loss of tertiary structural contacts, indicating that protein conformation is crucial for binding.
\end{abstract}

\section{Introduction}

The formation of protein-nucleic acid associations proceeds via hydrogen bonding. It was safely assumed by spectroscopic studies [5] that this association occurs by the attachment of the amino acid side chains to the nucleic acid bases. The historical theoretical investigation by Kumar and Govil [4] has enabled to establish a succession of the strength of binding of each amino acid to the nucleic acid bases and gave information about the geometry of the complexes so formed.

The presence of rare nucleic acid bases, e.g., 5-methylcytosine, $\mathrm{N}^{6}$-methyladenine [1] in the major groove in DNA, where the number of site-specific DNA-binding proteins recognise sites, point to the importance of the interactions between these bases with proteins.

As such, it is of interest to assess the binding site of the nitrogen bases in protein and the strength of this binding. Such studies lead to better understanding of the structural basis for the sequence-specific recognition of deoxynucleic acid and the molecular basis of gene regulation.

In this work we use ${ }^{1} \mathrm{H}$ NMR and spectrofluorescence technique in order to obtain model interaction of rare nucleic acid bases and protein.

\section{Experimental}

\subsection{Materials}

Adenine (Ade), adenosine (Ado) and 5'triphosphateadenosine (ATP) were purchased from Aldrich, $\mathrm{N}^{6}$-methyladenine $\left(\mathrm{N}^{6} \mathrm{mAde}\right), \mathrm{N}^{6}$-methyladenosine $\left(\mathrm{N}^{6} \mathrm{mAdo}\right)$ and 1-methyladenosine (1mAdo) - from Sigma, 1-methyladenine (1mAde), thymine (5mU), 5-methylcytosine $(5 \mathrm{mC})$ - from Serva. Uracil (U) was taken from Merck and 3-methyluracil (3mU) - from POCh S.A. Bovine serum albumin (BSA) and 
human serum albumin (HSA) crystallized and lyophilised, fraction V were from WSiS - Lublin and Fluka, respectively. The molecular weight of 66,000 and 66,500 for BSA and HSA respectively was used for the calculation.

$\mathrm{D}_{2} \mathrm{O}$ solutions were made in $\mathrm{D}_{2} \mathrm{O}$ of isotopic purity of $99.8 \%$ obtained from the INR Świerk, Poland.

\section{2. ${ }^{1}$ H NMR measurements}

${ }^{1} \mathrm{H}$ NMR spectra were recorded on BRUKER DPX 400 spectrometer $(400 \mathrm{MHz})$ at 300, 305, 313, 323,333 , and $343 \mathrm{~K} .{ }^{1} \mathrm{H}$ NMR line width were measured as half-hights of each peak of the spectra.

\subsection{Fluorescence measurements}

Fluorescence emission spectra were recorded at $298 \mathrm{~K}$ in KONTRON SFM fluorescence spectrophotometer with the slit widths $10 / 5 \mathrm{~nm}$. Excitation wavelengths were $280 \mathrm{~nm}$ (tryptophan fluorescence). Solutions of BSA and HSA were measured for fluorescence intensity. Readings were in arbitrary fluorescence units.

\subsection{Determination of the binding constant}

The binding of adenine and $\mathrm{N}^{6}$-methyladenine to bovine serum albumin (BSA) was measured using spectrofluorimetric technique. The association constants are determined from Scatchard equation,

$$
\frac{\left[\mathrm{L}_{\mathrm{b}}\right]}{\left[\mathrm{L}_{\mathrm{f}}\right] \cdot[\mathrm{BSA}]}=n \cdot K_{\mathrm{a}}-\frac{K_{\mathrm{a}} \cdot\left[\mathrm{L}_{\mathrm{b}}\right]}{[\mathrm{BSA}]},
$$

where $\left[\mathrm{L}_{\mathrm{f}}\right]$ and $\left[\mathrm{L}_{\mathrm{b}}\right]$ are the free and bound ligand concentration, $[\mathrm{BSA}]$ is the BSA concentration, $n$ is the number of binding sites and $K_{\mathrm{a}}$ is the association constant for the BSA-ligand complex.

Ligand bound concentration $\left[\mathrm{L}_{\mathrm{b}}\right]$ was calculated from the magnitude of the fluorescence decrease $-\Delta R_{\mathrm{F}}$ induced by ligand binding [2] from

$$
\left[\mathrm{L}_{\mathrm{b}}\right]=\frac{-\Delta R_{\mathrm{F}}}{-\Delta R_{\mathrm{F} \max }} \cdot[\mathrm{BSA}],
$$

where [BSA] is the total concentration of $\mathrm{BSA}$ and $-\Delta R_{\mathrm{Fmax}}$ is determined from a double reciprocal plot of a total ligand concentration versus observed fluorescence decrease $-\Delta R_{\mathrm{F}}$, extrapolated to infinite ligand concentration.

To examine the effect of temperature on the binding to BSA, the binding constant was determined at $298 \mathrm{~K}$ and $333 \mathrm{~K}$.

\section{Results and discussion}

\subsection{NMR line width data for methyl pyrimidine and adenine derivatives - effect of temperature}

The NMR analysis of each proton of a ligand in the presence of albumin under conditions where nonspecific effects of line broadening can be excluded, let us choose the selective changes in line width not in chemical shift (Table 1). 
Table 1

Chemical shifts $\delta \mathrm{ppm}^{\mathrm{a}}$ of pyrimidine and adenine derivatives in the presence of serum albumin

\begin{tabular}{|c|c|c|c|c|}
\hline \multirow[t]{2}{*}{ Ligand } & \multicolumn{2}{|c|}{ Aromatic protons } & \multirow{2}{*}{$\begin{array}{l}\text { Methyl protons } \\
\text { CH3 }\end{array}$} & \multirow{2}{*}{$\begin{array}{l}\text { Ligand/protein } \\
\text { molar ratio }\end{array}$} \\
\hline & H-6 & H-5 & & \\
\hline Uracil $^{\mathrm{c}}$ & $7.51(\mathrm{~d})^{\mathrm{b}}$ & $5.85(\mathrm{~d})^{\mathrm{b}}$ & & $132-1316$ \\
\hline $3 \mathrm{~m} \mathrm{Uracil}{ }^{\mathrm{c}}$ & $7.46(\mathrm{~d})^{\mathrm{b}}$ & $5.89(\mathrm{~d})^{\mathrm{b}}$ & $3.26(\mathrm{~N} 3)$ & $165-1316$ \\
\hline $5 \mathrm{~m} \operatorname{Uracil}(\mathrm{T})^{\mathrm{c}}$ & $7.38(\mathrm{~d})^{\mathrm{b}}$ & & $1.89(\mathrm{C} 5)$ & $165-1316$ \\
\hline 5m Cytosine & $7.35(\mathrm{~d})^{\mathrm{b}}$ & & 1.95 (C5) & $165-2632$ \\
\hline \multirow[t]{2}{*}{ Uridine $^{c}$} & $7.90(d)^{b}$ & $5.96(d)^{b}$ & & $270-1350$ \\
\hline & H-8 & $\mathrm{H}-2$ & $\mathrm{CH} 3$ & \\
\hline Adenine $^{c}$ & 8.11 & 8.07 & & $110-330$ \\
\hline $1 \mathrm{~m}$ Adenine $^{\mathrm{d}}$ & 8.05 & 7.99 & $3.51(\mathrm{~N} 1)$ & $110-330$ \\
\hline $\mathrm{N}^{6} \mathrm{~m}$ Adenine & 8.10 & 8.08 & 2.92 (N6) & $110-330$ \\
\hline Adenosine & 8.22 & 8.10 & & $110-660$ \\
\hline
\end{tabular}
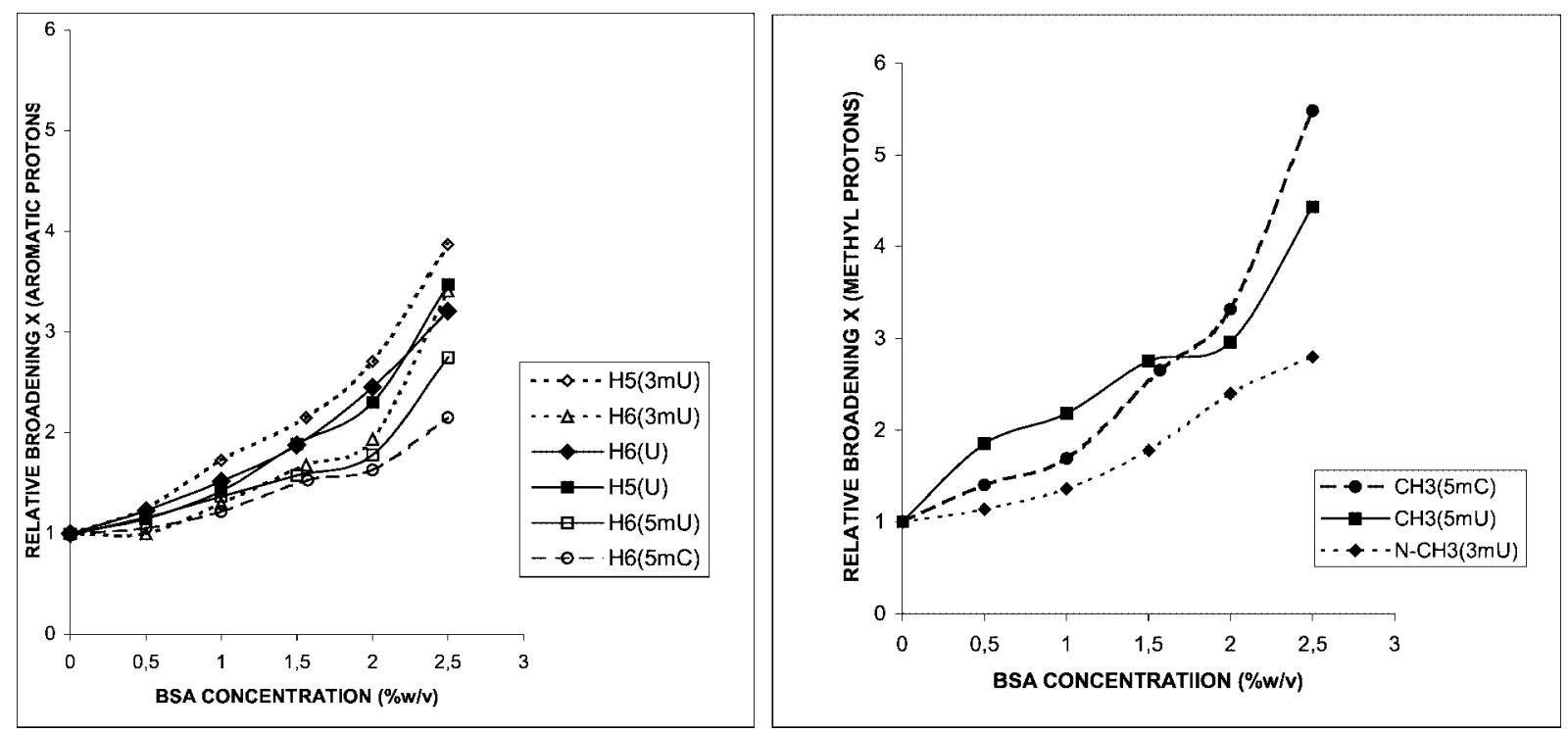

Fig. 1. Effect of albumin concentration (\%w/v) on NMR linewidth of aromatic protons (left side) and methyl protons (right side) of uracil derivatives. Relative broadening X calculated from Eq. (3).

The broadening effect of protein concentration was analysed after Jardetzky and Roberts [3] using relative broadening coefficient:

$$
X=\frac{\Delta \nu_{1 / 2(\mathrm{~L}, \mathrm{BSA})}}{\Delta \nu_{1 / 2(\mathrm{~L})}}
$$

where $\Delta \nu_{1 / 2}$ is the half width of the individual signal of ligand in the presence and absence of protein. 

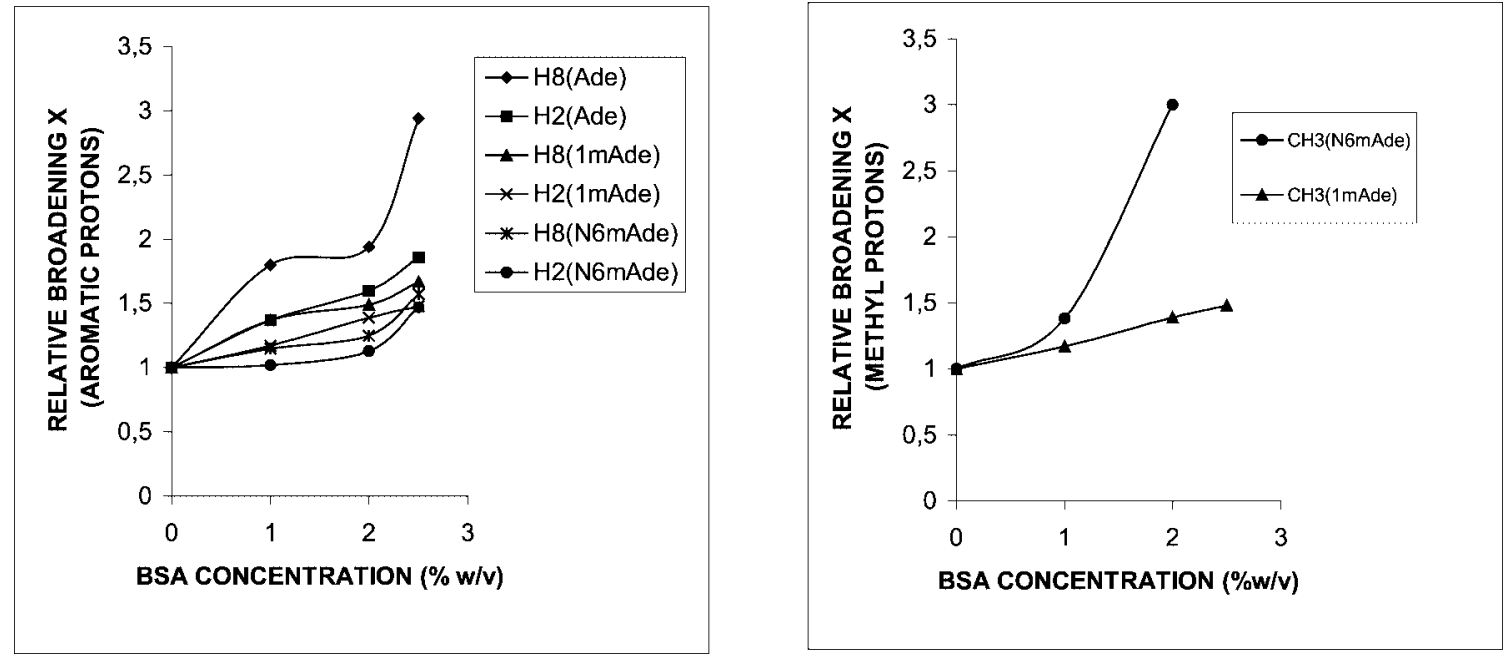

Fig. 2. Effect of albumin concentration (\%w/v) on NMR linewidth of aromatic protons (left side) and methyl protons (right side) of adenine derivatives. Relative broadening X calculated from Eq. (3).

The results shown in Fig. 1 for pyrimidine derivatives and in Fig. 2 for adenine ones display the greater effect of serum albumin on NMR line width of methyl protons than aromatic ones for the same ligand. Interesting is that NMR line width of C5 methyl protons are broadened in the presence of $2.5 \% \mathrm{w} / \mathrm{v}$ BSA as twice much higher as of N3 methyl (Fig. 1). Similar effect we can observe in methyl adenine-protein complexes, where the line assigned to the $\mathrm{N}^{6}$ methyl protons is more broadened than this assigned to $\mathrm{N} 1$ methyl group.

The absence of change in chemical shifts of ligands at increased serum albumin concentration (Table 1) exclude the possibility of the formation of strong complexes pyrimidine and adenine derivatives-protein. The selectivity in broadening of NMR line width in the presence of protein Figs 1 and 2, reflecting the selective increase in the correlation time of the individual part of ligand molecule (aromatic ring, methyl group), point not only to hydrophobic interactions between methyl groups and protein, postulated in [6] but also shows that methyl group in C5 position in pyrimidine ring (as in 5-cytosine and in thymine) and the methyl group in N6 position in adenine plays a particular role in these interactions.

The comparative study of temperature effect on line width of ligand in complex with BSA was made by use of narrowing coefficient:

$$
U=\frac{\Delta \nu_{1 / 2(\mathrm{~L}, \mathrm{~T})}-\Delta \nu_{1 / 2(\mathrm{~L}, \mathrm{BSA}, \mathrm{T})}}{\Delta \nu_{1 / 2(\mathrm{~L}, \mathrm{BSA}, 298)}-\Delta \nu_{1 / 2(\mathrm{~L}, \mathrm{BSA}, \mathrm{T})}} \cdot 100 \%,
$$

where $\Delta \nu_{1 / 2}$ is the half width of the individual signal of ligand with and without BSA at temperature $298 \mathrm{~K}$ or $T$ as indicated in subscripts.

The selectivity of the narrowing effect of temperature on NMR line width of methyl adenine derivatives complexed with BSA is shown in Fig. 3. We can see that increase of temperature leads to decrease of resonance line broadened in the presence of protein, disscused by us in [7] for adenine and 8-ethyl-9Nmethyladenine. If to compare the narrowing of the signal assigned to N6 methyl and N1 methyl group we can see the greater decrease of resonance signal of N6 methyl protons. This phenomenon can be explain by gradual removing of ligands from their binding site when the tertiary structure of BSA undergoes 

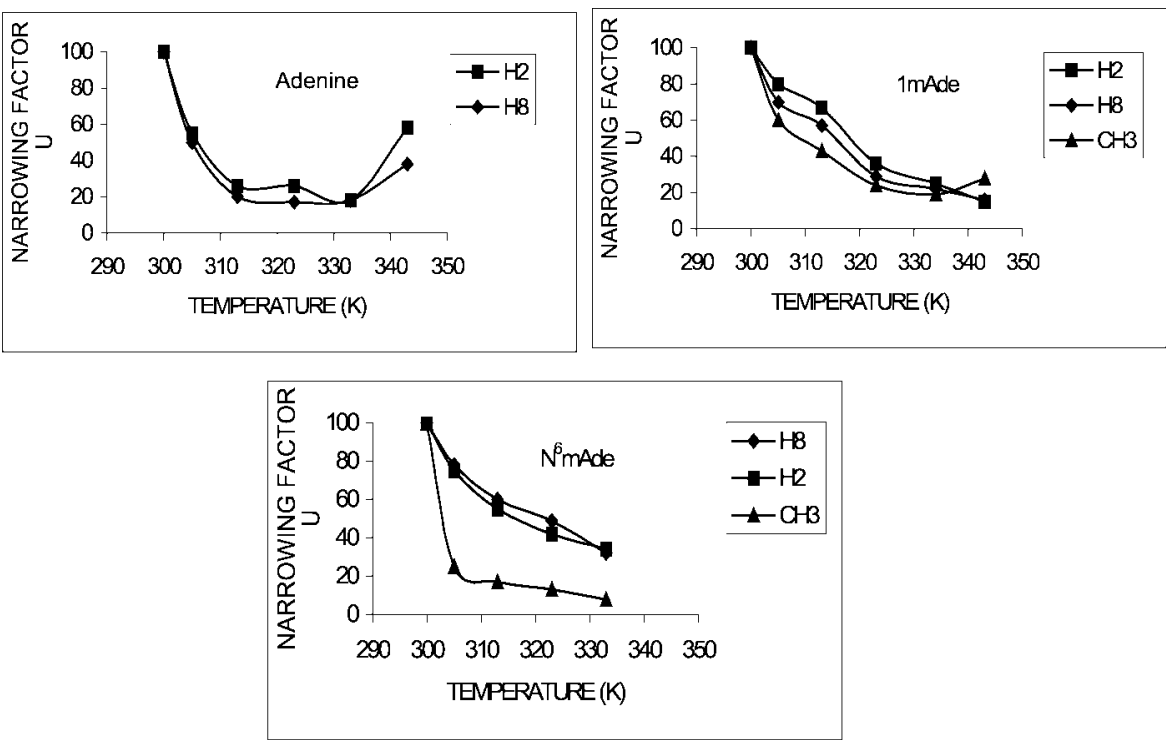

Fig. 3. Effect of temperature (K) on NMR linewidth of adenine, 1-methyladenine and $\mathrm{N}^{6}$ methyl adenine. Narrowing factor $\mathrm{U}$ calculated from Eq. (4).

unfolding. Since the N6 methyl group was postulated to interact with hydrophobic interior of protein it is the most exposed on the changes of protein structure.

During the heating the unfolding of tertiary structure of serum albumin takes places till $333 \mathrm{~K}$. Increase of line width of protons of adenine and 1-methyladenine between 333 and $343 \mathrm{~K}$ can be explained by aggregation (due to disulphide exchange) of BSA.

\subsection{Quenching effect on protein fuorescence}

The emission fluorescence spectra of the complexes of adenine and its methyl-derivatives with bovine serum albumin $\left(\lambda_{\mathrm{exc}}=280 \mathrm{~nm}\right)$ show a temperature independent maximum at $334 \mathrm{~nm}$, characteristic for HSA and BSA tryptophanyl group absorption. At $333 \mathrm{~K}$ fluorescence intensities at $334 \mathrm{~nm}$ decreased by 10,15 and $20 \%$ for adenine and its non-methylated derivatives and 45, 60 and $70 \%$ for methylated derivatives used as a quenchers (ligand: BSA molar ratio $25: 1$ ) (Fig. 4). This quenching effect is smaller than decrease of fluorescence induced by the same ligand at 298 K (Fig. 4).

The hydrophobic interaction of adenine derivatives with protein occurring close to fluorophore (tryptophan) site leads to a transfer energy to the ligand from tryptophan absorption. The transfer arises preferentially to adjacent residues, which are buried. Trp is located in the interior of the protein structure as single Trp214 in HSA or as Trp 135 and Trp 214 in BSA.

The similar quenching effect for HSA and BSA for the same adenine derivatives used as the quencher at $\lambda_{\mathrm{exc}}=280 \mathrm{~nm}$ point to interactions with $\operatorname{Trp} 214$, located in subdomain IIA, not with Trp 135, present in BSA only.

Typical plot $\left[\mathrm{L}_{\mathrm{b}}\right] /\left[\mathrm{L}_{\mathrm{f}}\right][\mathrm{BSA}]$ against $\left[\mathrm{L}_{\mathrm{b}}\right] /[\mathrm{BSA}]$ at various temperature is shown in Fig. 5 .

A linear relationship was pretty good. As can be seen in Fig. 5, the association constants are dependent on the temperature in the temperature range examined. Binding constant to serum albumin at $298 \mathrm{~K}$ was calculated as $1.05 \times 10^{3} \mathrm{M}^{-1}$ for adenine and $7.24 \times 10^{3} \mathrm{M}^{-1}$ for $\mathrm{N}^{6}$-methyladenine. When temperature 

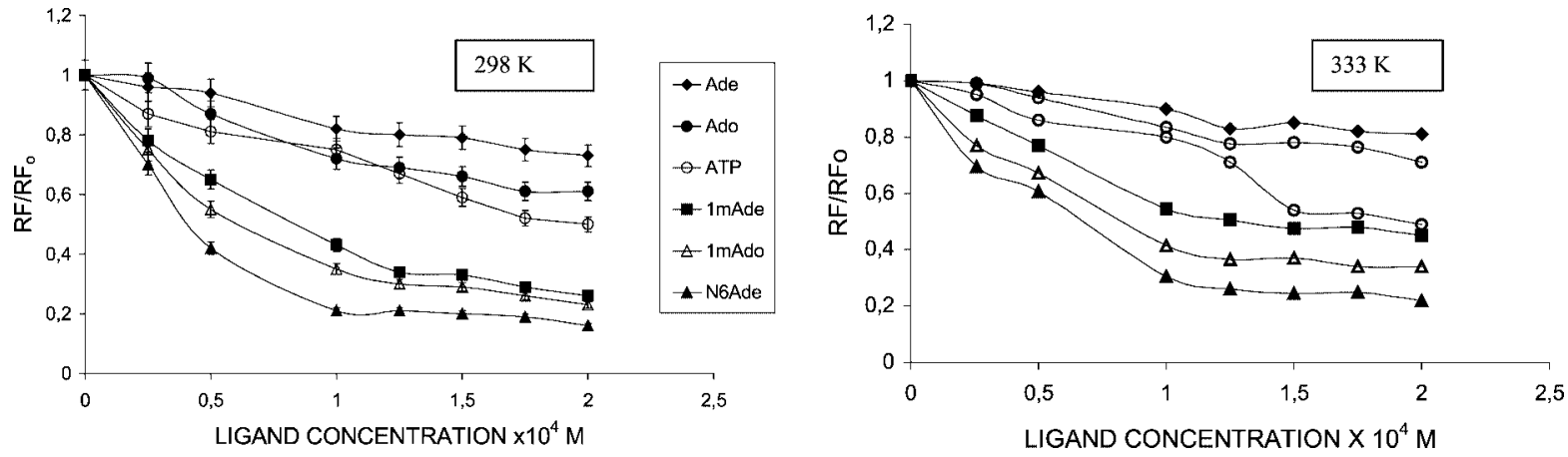

Fig. 4. Fluorimetric titration of the tryptophan fluorescence in BSA by $\checkmark$ Ade, $\bullet-$ Ado, o - ATP, $\mathbf{\square}-1$ mAde, $\triangle-1$ mAdo and $\boldsymbol{\Delta}-\mathrm{N}^{6}$ Ade monitored at $335 \mathrm{~nm}$. Temperature 298 and $333 \mathrm{~K}$.

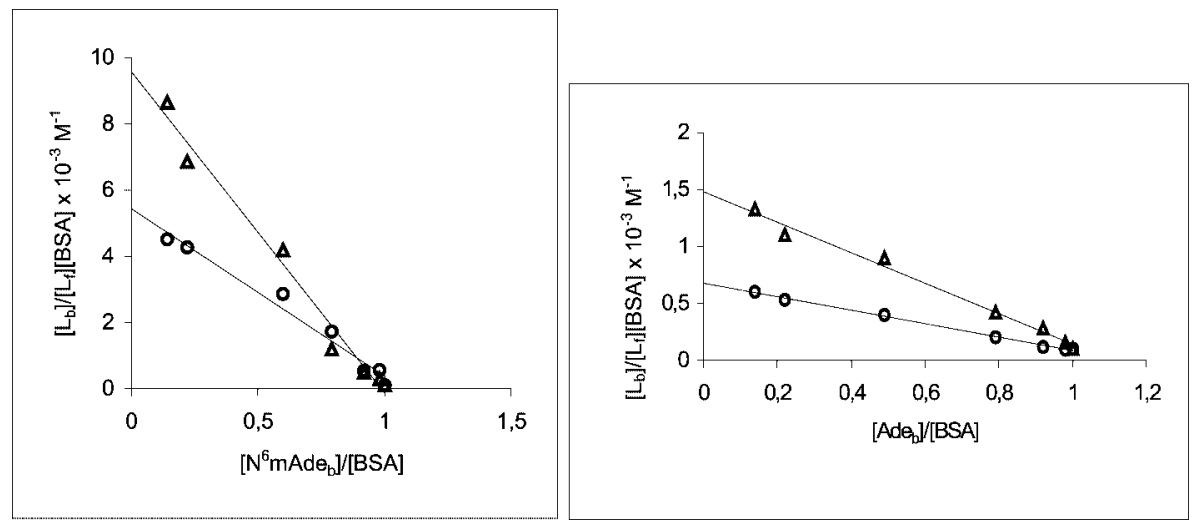

Fig. 5. Scatchard plots of adenine (Ade) and N6-methyladenine ( $\mathrm{N}^{6} \mathrm{mAde}$ ) binding to bovine serum albumin (BSA) at: $\triangle-$ $293 \mathrm{~K}$ and $\circ-333 \mathrm{~K}$.

raises to $333 \mathrm{~K}$ an association constant decreases 2.2 times for adenine and 1.8 times for $\mathrm{N}^{6} \mathrm{mAde}$. The presence of $\mathrm{N}^{6}$ methyl group in adenine molecule led to a 7-times increase in association constant.

\section{Conclusions}

1. Methyl groups of nucleic acid bases and especially C5-methyl group in pyrimidine ring and $\mathrm{N}^{6}$ methyl group in adenine take an important role in interactions with protein.

The more so that they are located in major groove in DNA where the number of site-specific DNAbinding proteins recognise site.

2. The nucleic acid bases interact with hydrophobic subdomain IIA of human and bovine serum albumin.

3. The presence of $\mathrm{N}^{6}$ methyl group in adenine molecule led to an increase in association constant of about 7-times.

4. The destabilization of protein structure causes loss of tertiary structural contacts, indicating that protein conformation is crucial for binding. 


\section{References}

[1] A. Fliess, W. Heiner, A. Rosenthal, K. Schwellnus, H. Blocker, R. Frank and A. Pingould, Role of thymidine residues in DNA recognition by the EcoRl and EcoRV restriction endonucleases, Nucl. Acids Res. 14 (1986), 3463-3474.

[2] T. Hiratsuka, Conformational changes in the $23 \mathrm{kD} \mathrm{NH}_{2}$-terminal peptide segment of myosin, ATPase associated with ATP hydrolysis, J. Biol. Chem. 265 (1990), 18 786-18 790.

[3] O. Jardetzky and G.C. Roberts, in: NMR in Molecular Biology, Academic Press, New York, 1981.

[4] N.N. Kumar and G. Govil, Theoretical studies on protein-nucleic acid interactions. II. Hydrogen bonding of amino acid side chains with bases and base pairs of nucleic acids, Biopolymers 23 (1984), 1995-2008.

[5] G. Lancelot, R. Mayer and C. Helene, Models of interaction between nucleic acids and proteins. Hydrogen bonding of arginine with nucleic acid bases, phosphate groups and carboxylic acids, Biochim. Biophys. Acta 564 (1979), 181-190.

[6] A. Sułkowska and A. Michnik, Proton NMR studies on the interaction of alkyl derivatives of pyrimidine bases, their nucleosides and nucleotides with bovine serum albumin, J. Mol. Struct. 348 (1995), 73-76.

[7] A. Sułkowska, Temperature effect on the stability of the complexes between purine derivatives and serum albumin, J. Mol. Struct. 410-411 (1997), 23-25. 


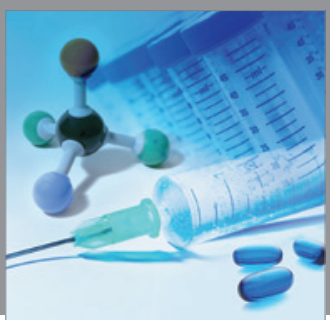

International Journal of

Medicinal Chemistry

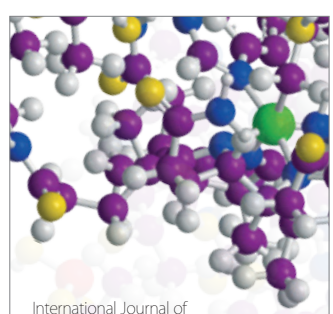

Carbohydrate Chemistry

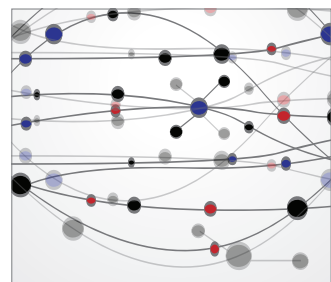

The Scientific World Journal
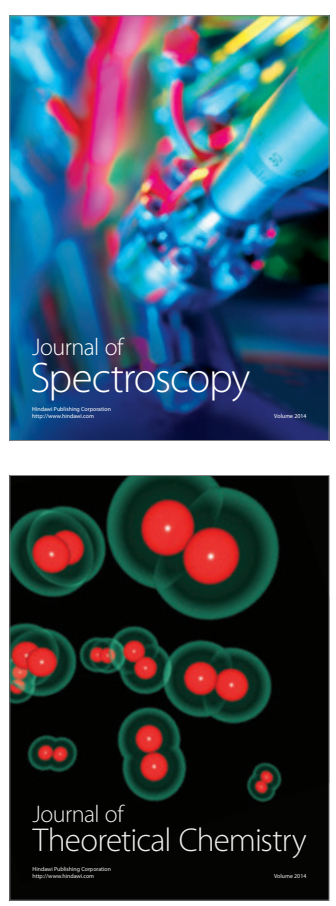
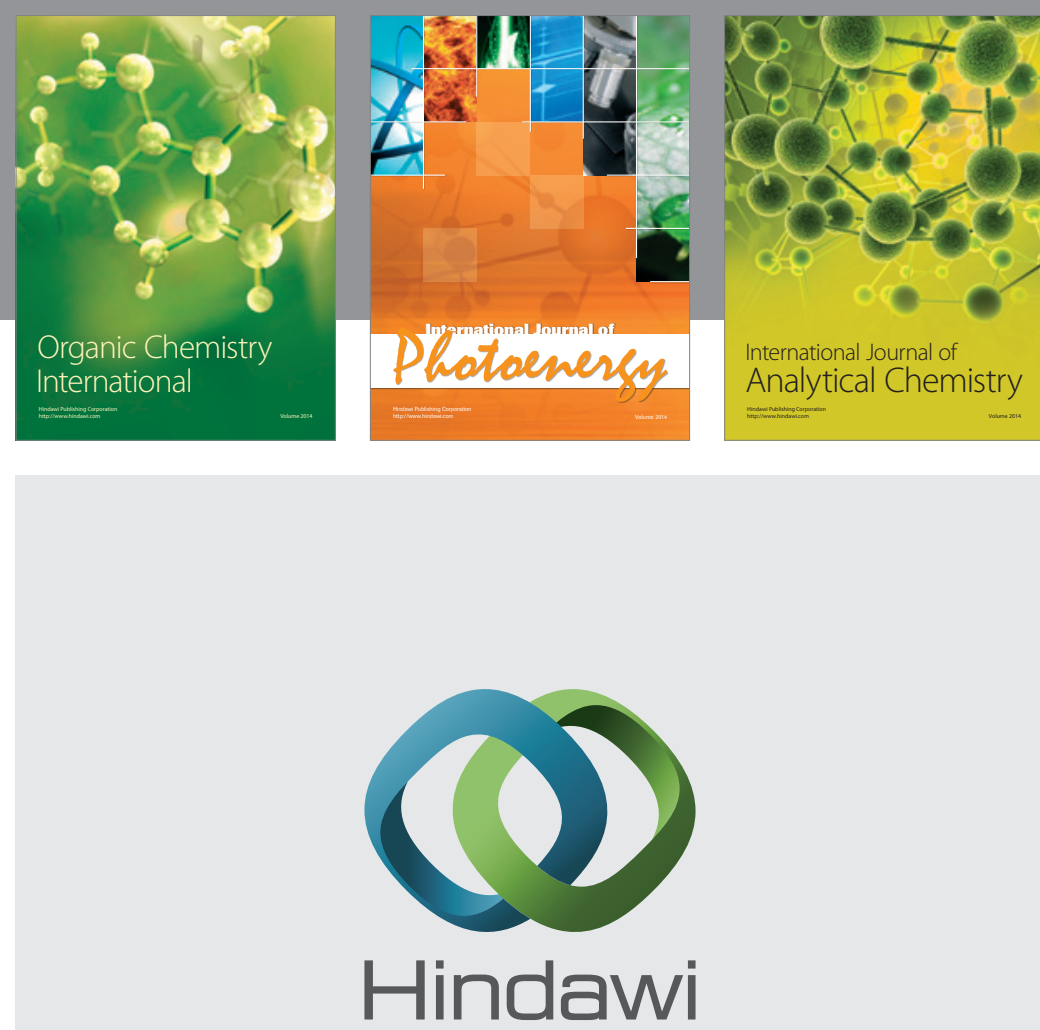

Submit your manuscripts at

http://www.hindawi.com
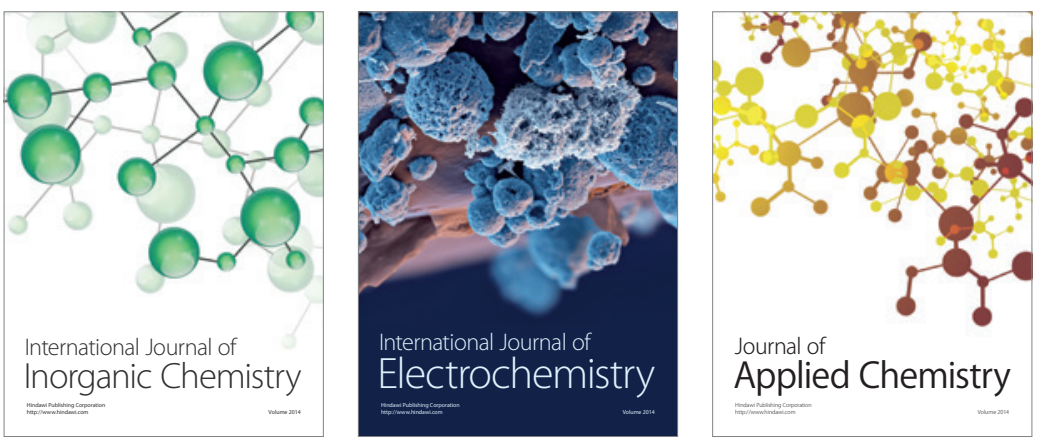

Journal of

Applied Chemistry
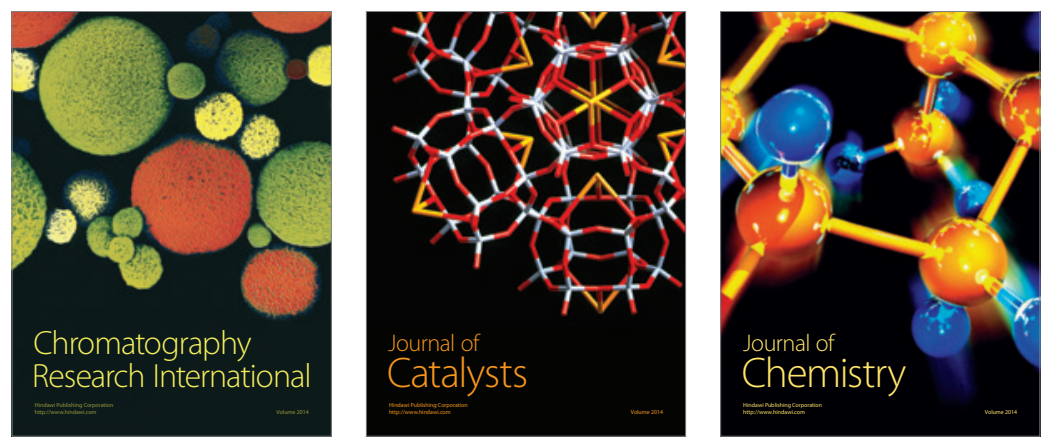
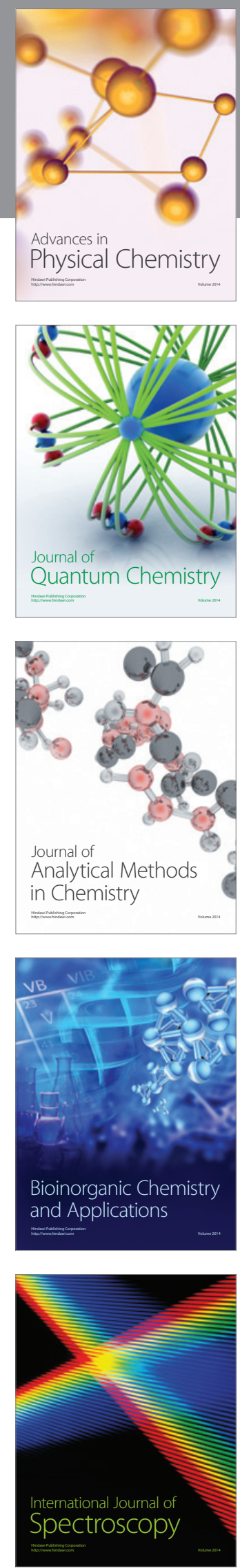